\title{
SEC14-Like Protein 1
}

National Cancer Institute

\section{Source}

National Cancer Institute. SEC14-Like Protein 1. NCI Thesaurus. Code C111871.

SEC14-like protein 1 (715 aa, $\sim 81 \mathrm{kDa}$ ) is encoded by the human SEC14L1 gene. This protein may be involved in intracellular transport. 